\title{
Neurologic Disorders in Immunocompetent Patients with Autochthonous Acute Hepatitis E
}

\author{
H. Blasco Perrin, P. Cintas, F. Abravanel, R. Gérolami, L. d'Alteroche, J.-N. Raynal, \\ L. Alric, E. Dupuis, L. Prudhomme, E. Vaucher, P. Couzigou, J.-M. Liversain, \\ C. Bureau, J.-P. Vinel, N. Kamar, J. Izopet, J.-M. Peron
}

\begin{abstract}
Medscape ACTIVITY
EUCAIION
Medscape, LLC is pleased to provide online continuing medical education (CME) for this journal article, allowing clinicians the opportunity to earn CME credit.

This activity has been planned and implemented in accordance with the Essential Areas and policies of the Accreditation Council for Continuing Medical Education through the joint providership of Medscape, LLC and Emerging Infectious Diseases. Medscape, LLC is accredited by the ACCME to provide continuing medical education for physicians.

Medscape, LLC designates this Journal-based CME activity for a maximum of 1.0 AMA PRA Category 1 Credit(s) ${ }^{T M}$. Physicians should claim only the credit commensurate with the extent of their participation in the activity.

All other clinicians completing this activity will be issued a certificate of participation. To participate in this journal CME activity: (1) review the learning objectives and author disclosures; (2) study the education content; (3) take the post-test with a $75 \%$ minimum passing score and complete the evaluation at http://www.medscape.org/journal/eid; (4) view/print certificate.
\end{abstract}

Release date: October 19, 2015; Expiration date: October 19, 2016

\section{Learning Objectives}

Upon completion of this activity, participants will be able to:

- Distinguish overall aspects of neurologic disorders occurring in immunocompetent patients infected with hepatitis $E$ virus, based on a retrospective case series

- Discuss mononeuritis multiplex occurring in immunocompetent patients infected with hepatitis $E$ virus

- Discuss Parsonage-Turner syndrome occurring in immunocompetent patients infected with hepatitis E virus.

\section{CME Editor}

Carol E. Snarey, MA, Copyeditor, Emerging Infectious Diseases. Disclosure: Carol E. Snarey, MA, has disclosed no relevant financial relationships.

\section{CME Author}

Laurie Barclay, MD, freelance writer and reviewer, Medscape, LLC. Disclosure: Laurie Barclay, MD, has disclosed no relevant financial relationships.

\section{Authors}

Disclosures: Hélène Blasco-Perrin, MD; Pascal Cintas, MD; Florence Abravanel, PharmD, PhD; René Gérolami, MD, PhD; Louis d'Alteroche, MD; Jean-Noël Raynal, MD; Emmanuel Dupuis, MD; Laurent Prudhomme, MD, PhD; Emmanuel Vaucher, MD; Patrice Couzigou, MD; Jean-Michel Liversain, MD; Louis Buscail, MD, PhD; Jean-Pierre Vinel, MD; Nassim Kamar, MD, PhD; Jacques Izopet, PharmD, PhD; and Jean-Marie Peron, MD, PhD, have disclosed no relevant financial relationships. Laurent Alric, MD, PhD, has disclosed the following relevant financial relationships: served as an advisor or consultant for MSD, BMS, Gilead; served as a speaker or a member of a speakers bureau for MSD; received grants for clinical research from Roche, Janssen, MSD, Gilead. Christophe Bureau, MD, PhD, has disclosed the following relevant financial relationships: served as an advisor or consultant for Norgine Inc.; served as a speaker or a member of a speakers bureau for W.L. Gore \& Associates, Inc.; received grants for clinical research from W.L. Gore \& Associates, Inc.

Author affiliations: Hôpital Purpan-CHU Toulouse, Toulouse, France (H. Blasco Perrin, P. Cintas, F. Abravanel, L. Alric, C. Bureau, J.-P. Vinel, J. Izopet, J.M. Peron); Hôpital de La Conception-CHU Marseille, Marseille, France (R. Gérolami); Hôpital Trousseau-CHU Tours, Tours, France (L. d'Alteroche); Clinique de I'Union, I'Union, France (J.-N. Raynal); Clinique Pasteur, Toulouse (E. Dupuis); CHIC Castres-Mazamet, Castres-Mazamet, France (L. Prudhomme); CH Narbonne, Narbonne, France (E. Vaucher); Hôpital du Haut-Lévêque-CHU Bordeaux, Bordeaux, France (P. Couzigou); CH Mont de Marsan, Mont de Marsan, France (J.-M. Liversain); Hôpital Ranguei-CHU Toulouse, Toulouse (L. Buscail, N. Kamar)

DOI: http://dx.doi.org/10.3201/eid2111.141789 
Neurologic disorders, mainly Guillain-Barré syndrome and Parsonage-Turner syndrome (PTS), have been described in patients with hepatitis $E$ virus (HEV) infection in industrialized and developing countries. We report a wider range of neurologic disorders in nonimmunocompromised patients with acute HEV infection. Data from 15 French immunocompetent patients with acute HEV infection and neurologic disorders were retrospectively recorded from January 2006 through June 2013. The disorders could be divided into 4 main entities: mononeuritis multiplex, PTS, meningoradiculitis, and acute demyelinating neuropathy. HEV infection was treated with ribavirin in 3 patients (for PTS or mononeuritis multiplex). One patient was treated with corticosteroids (for mononeuropathy multiplex), and 5 others received intravenous immunoglobulin (for PTS, meningoradiculitis, Guillain-Barré syndrome, or Miller Fisher syndrome). We conclude that pleiotropic neurologic disorders are seen in HEV-infected immunocompetent patients. Patients with acute neurologic manifestations and aminotransferase abnormalities should be screened for HEV infection.

$\mathrm{H}^{2}$ epatitis E virus (HEV) infection is an emerging autochthonous disease in industrialized countries (1). Locally acquired (autochthonous) HEV 3 or HEV 4 infections are believed to be a porcine zoonosis. The virus typically affects middle-aged or elderly men and can cause severe hepatitis, particularly in patients with an underlying liver disease (2). Chronic HEV infection occurs in recipients of a solid-organ transplant, in patients with hematologic malignancies, and in patients with HIV infection $(3,4)$. Neurologic symptoms have been reported in up to $5 \%$ of patients with an HEV infection, indicating that HEV could have a specific neurotropism (5); most patients in this preliminary study were immunosuppressed. In developing countries, cases describing neurologic involvement during acute HEV infection have also been reported $(6,7)$ : most concerned Guillain-Barré syndrome (GBS) and ParsonageTurner syndrome (PTS). Peripheral neuropathy, smallfiber neuropathy, and myositis have also been described $(8,9)$. Peripheral nervous system tropism is not exclusive, and rare cases of myelitis and encephalitis have also been reported (10). Recently, studies of 2 national cohorts (in the United Kingdom and the Netherlands) have found that GBS and PTS were associated with acute HEV infection in $5 \%$ and $10 \%$ of cases, respectively $(11,12)$. Here we describe an additional range of neurologic manifestations that were found during acute autochthonous HEV infection in immunocompetent patients.

\section{Patients and Methods}

This retrospective multicenter study was conducted in France from January 2006 through June 2013. All members of the French Liver Association (Association Française pour l'Etude du Foie, 500 members) were sent a newsletter inviting them to report cases of HEV infection in which neurologic symptoms were experienced. Data were recorded from patients with neurologic disorders, regardless of the symptoms exhibited during the course of acute HEV infection. This retrospective sampling was likely to capture most patients in France who had neurologic symptoms during acute HEV infection. A second newsletter was sent 6 months later to maximize the completeness of reporting. HEV infection was diagnosed by detecting anti-HEV IgM, HEV RNA, or both in serum or fecal samples from patients with elevated aminotransferase levels. All cases occurred in France, and all patients gave their informed consent.

The EIAgen (Adaltis, Eurobio, Bologna, Italy) and Wantai (Wantai Biologic Pharmacy Enterprise Co., Beijing, China) kits were used to detect antibodies (13). Both tests are highly specific and sensitive for detecting IgM against HEV. HEV RNA from serum, fecal samples, or cerebrospinal fluid (CSF) was detected by using a real-time PCR as described $(3,14)$. All other causes of acute hepatitis were excluded, and patients had no co-infections. All patients were screened for other causes of disease with immunoassays (antinuclear antibodies, antipolynuclear neutrophil cytoplasmic antibodies) and underwent viral serologic testing (hepatitis B virus, hepatitis C virus, HIV, Epstein-Barr virus, cytomegalovirus). Campylobacter was also screened for. The cases of patients 5 and 12 have been reported (14).

Phylogenetic analyses were performed by sequencing a 347-nt fragment within the open reading frame 2 region as described (15). Nucleotide identity was analyzed with BioEdit software version 7.0.9.0 (http://www.mbio.ncsu. edu/BioEdit/bioedit.html).

\section{Statistical Analyses}

Data are presented as their medians (ranges) or their means (SDs). Student $t$-test was used to compare the quantitative variables. A $p$ value $<0.05$ was considered significant.

\section{Results}

\section{Patient Characteristics and Clinical Outcomes}

Fifteen patients ( 7 women, 8 men) from 7 different hospitals were included in this study. The clinical characteristics of the patients are reported in Table 1 . The median age was 55 years (range 25-77 years). The median follow-up period was 42 weeks (range 4-161 weeks). All patients were immunocompetent. All but 1 lived in southern France: 11 lived in the southwest, 3 in the southeast, and 1 in central France.

No patient had underlying chronic liver disease; 2 patients had jaundice, 10 had asthenia, 5 had arthromyalgia, and 3 had fever. Three patients had neurologic symptoms only. Their biological characteristics are reported in Table 2. All patients had elevated liver enzyme levels, and none 
Table 1. Clinical characteristics of 15 patients with hepatitis E virus-linked neurologic disorders, France, January 2006-June 2013*

\begin{tabular}{|c|c|c|c|c|c|c|}
\hline Patient no. & $\begin{array}{l}\text { Neurologic } \\
\text { pathology }\end{array}$ & $\begin{array}{l}\text { Age, } \\
\text { y/sex }\end{array}$ & Treatment & Other symptoms & $\begin{array}{l}\text { Neurologic symptoms } \\
\text { at last follow-up }\end{array}$ & $\begin{array}{l}\text { Follow up } \\
\text { times, wk }\end{array}$ \\
\hline 1 & $\mathrm{MM}$ & $59 / \mathrm{M}$ & None & Asthenia & No & 10 \\
\hline 2 & MM & $44 / F$ & None & Fever, asthenia, arthromyalgia & Yes & 4 \\
\hline 3 & MM & $65 / \mathrm{M}$ & Corticosteroids & Asthenia & No & 157 \\
\hline 4 & MM & $25 / F$ & None & None & No & 33 \\
\hline 5 & MM & $49 / \mathrm{M}$ & None & None & No & NA \\
\hline 6 & MM & $77 / F$ & RBV & None & No & 44 \\
\hline 7 & PTS & $51 / \mathrm{M}$ & RBV + IVIg & Arthromyalgia, asthenia & No & 100 \\
\hline 8 & PTS & $55 / F$ & None & Asthenia, arthromyalgia & Yes & 126 \\
\hline 9 & PTS & $56 / \mathrm{M}$ & None & Asthenia & Yes & 42 \\
\hline 10 & PTS & $56 / \mathrm{M}$ & RBV + IVlg & Asthenia & Yes & 16 \\
\hline 11 & MR & $74 / \mathrm{M}$ & IV $\lg$ & Arthromyalgia, asthenia & No & 77 \\
\hline 12 & MR & $54 / F$ & None & Fever, nausea & No & NA \\
\hline 13 & MR & $33 / F$ & None & Fever, arthromyalgia & No & 161 \\
\hline 14 & GBS & $60 / F$ & IV Ig & Asthenia, acute low back pain & Yes & 5 \\
\hline 15 & MFS & $54 / \mathrm{M}$ & IV lg & Asthenia, anorexia & Yes & 13 \\
\hline
\end{tabular}

experienced liver failure. Median enzyme levels at diagnosis were the following: alanine aminotransferase level at diagnosis was $495 \mathrm{IU} / \mathrm{L}$ (range 49-3,641 IU/L; reference range 10-41 IU/1), aspartate aminotransferase 124 IU/L (range 37-1,742 IU/L; reference range 15-41 IU/1), bilirubin $15 \mu \mathrm{mol} / \mathrm{L}$ (range $4-101 \mu \mathrm{mol} / \mathrm{L}$; reference range 3-21 $\mu \mathrm{mol} / \mathrm{l}$ ), alkaline phosphatase $254 \mathrm{IU} / \mathrm{L}$ (range 88-704 IU/L; reference range 36-126 IU/l), g-glutamyl transferase $185 \mathrm{IU} / \mathrm{L}$ (range 33-783 IU/L; reference range 7-64 IU/l). Median prothrombin time was $96 \%$ (range $76 \%-100 \%$ ).

All patients had IgM against HEV; 13 had IgG against HEV and 2 did not. Serum specimens of 14 patients underwent HEV PCR, and specimens from 11 patients were positive for HEV (Table 2). The median plasma HEV RNA concentration was $4.40 \log$-copies $/ \mathrm{mL}$ (range 2.12-5.83).

We were able to sequence 7 virus strains from the patients: all belonged to genotype $3 \mathrm{f}$, the main genotype identified in France. Phylogenetic analyses were conducted with these strains and HEV strains obtained by the French National Reference Center from patients who did not exhibit a neurologic disorder (Figure). The strains were scattered across the phylogenetic tree and were only $87.0 \%-93.5 \%$ identical.

Two patients had eaten game (wild boar and deer). All other patients had eaten pork. All patients had liver enzyme levels within the reference range at the last follow-up.

\section{Neurologic Symptoms}

Fourteen patients had been hospitalized. Neurologic symptoms were classified into 4 categories: mononeuritis multiplex, PTS, meningoradiculitis, and acute inflammatory demyelinating polyradiculoneuropathy (Table 3 ).

\section{Mononeuritis Multiplex}

Six patients (3 men and 3 women, patients 1-6) had mononeuritis multiplex; their median age was 54 years (range 25-77 years). Mononeuritis multiplex was defined by asymmetric, asynchronous involvement of the noncontiguous nerve trunks. All patients had experienced neuropathic pain and paresthesia in $\geq 1$ nerve segments with hyporeflexia or areflexia. For 3 patiens, an electromyogram showed asymmetric axonal neuropathy, and various patterns of nerve involvement were observed. Patients 1 and 6 had confluent but asymmetric $(>50 \%)$ lower-limb neuropathy (musculocutaneous and external saphenous). Patients 3 and 4 had multiple radicular or proximal troncular neuropathies, and patient 5 had troncular median and internal brachial cutaneous-nerve involvement. Three patients had asthenia and 1 had jaundice; HEV RNA was detected by PCR in serum samples from 4 patients (patients $1,2,5,6)$.

One patient (patient 6) received specific antiviral treatment. He was given ribavirin, initially at a dose of $400 \mathrm{mg}$ for 7 days $(5.5 \mathrm{mg} / \mathrm{kg} / \mathrm{d})$ and was then given $600 \mathrm{mg} /$ day $(8.5 \mathrm{mg} / \mathrm{kg} / \mathrm{d})$ for 3 months. A serum specimen was negative for HEV after 10 days of treatment. Patient 3 was given corticosteroids for 10 weeks. Five patients had no sequelae at the last follow-up (median 33 weeks [range 4-157 weeks]). One patient (patient 2), at the last followup at 4 weeks, had ongoing paresthesia in a nerve segment in the lower limbs.

\section{PTS}

Four patients ( 3 men and 1 woman, patients 7-10) exhibited PTS, also known as neuralgic amyotrophy. Their median age was 55.5 years (range 51-56 years). These patients sought treatment at the hospital for asthenia and acute neuropathic pain in the shoulder. PTS was bilateral but asymmetric in 3 patients. Asymmetric paresis and amyotrophia appeared within a few days, with the concomitant decrease in pain. Tendon reflexes were reduced or eliminated in $2 \mathrm{pa}-$ tients (patients 9 and 10). For 3 patients, an electromyogram 
Neurologic Disorders in Patients with Hepatitis E

Table 2. Liver test results and virologic characteristics of 15 patients with hepatitis $E$ virus-linked neurologic disorders, France, January 2006-June 2013*

\begin{tabular}{|c|c|c|c|c|c|c|c|c|c|c|c|c|}
\hline $\begin{array}{l}\text { Patient } \\
\text { no. }\end{array}$ & Diagnosis & $\begin{array}{c}\text { AST, } \\
\text { IU/L }\end{array}$ & $\begin{array}{l}\mathrm{ALT} \\
\mathrm{IU} / \mathrm{L}\end{array}$ & $\begin{array}{c}\text { Bilirubin, } \\
\mu \mathrm{mol} / \mathrm{L}\end{array}$ & $\begin{array}{l}\text { ALKP, } \\
\text { IU/L }\end{array}$ & $\begin{array}{l}\text { GGT, } \\
\text { IU/L }\end{array}$ & PT, \% & GT & Serology & $\begin{array}{l}\text { Serum viral load, } \\
\text { log copies/mL }\end{array}$ & $\begin{array}{l}\text { PCR } \\
\text { stools }\end{array}$ & $\begin{array}{l}\text { PCR } \\
\text { CSF }\end{array}$ \\
\hline 1 & MM & 69 & 256 & 8.6 & 254 & 323 & 92 & $3 f$ & $\operatorname{lgG}+/ \lg M+$ & 4.92 & NA & NA \\
\hline 2 & MM & 507 & 756 & 17 & 540 & 187 & 90 & $3 f$ & $\operatorname{lgG}+/ \lg M+$ & 5 & Pos & NA \\
\hline 3 & MM & NA & 3,641 & 90 & NA & NA & 80 & NA & $\lg \mathrm{G}+/ \lg \mathrm{M}+$ & Neg & $\mathrm{Neg}$ & NA \\
\hline 4 & MM & 54 & 120 & 10 & NA & 95 & 100 & NA & lgG+/lgM+ & Neg & Neg & NA \\
\hline 5 & MM & 50 & 118 & 14 & 90 & 95 & 95 & NA & $\operatorname{lgG}+/ \lg M+$ & Pos & NA & Neg \\
\hline 6 & MM & 71 & 119 & 14 & 430 & 131 & 100 & $3 f$ & lgG-/lgM+ & 5.57 & Pos & NA \\
\hline 7 & PTS & 897 & 1,834 & 42 & 336 & 383 & 88 & NA & $\operatorname{lgG}+/ \lg M+$ & 2.12 & NA & NA \\
\hline 8 & PTS & 1.330 & 1,900 & 15 & 194 & 182 & 95 & NA & $\operatorname{lgG}+/ \lg M+$ & 2.81 & NA & NA \\
\hline 9 & PTS & 601 & 1,376 & 15 & 231 & 601 & 95 & NA & $\operatorname{lgG}+/ \lg M+$ & NA & NA & NA \\
\hline 10 & PTS & 135 & 495 & 17 & 659 & 740 & 100 & $3 f$ & $\operatorname{lgG}+/ \lg M+$ & 3.89 & Pos & NA \\
\hline 11 & MR & 1.742 & 822 & 101 & 704 & 528 & 76 & $3 f$ & $\operatorname{lgG}+/ \lg M+$ & 5.83 & Pos & Pos \\
\hline 12 & MR & 221 & 566 & 11 & 124 & 184 & 100 & NA & $\operatorname{lgG}+/ \lg M+$ & Pos & NA & Pos \\
\hline 13 & MR & 100 & 246 & 4.7 & 248 & 33 & 98 & $3 f$ & lgG-/lgM+ & 2.9 & Pos & Neg \\
\hline 14 & AIDP & 113 & 384 & 34.2 & 474 & 783 & 100 & $3 f$ & $\operatorname{lgG}+/ \lg M+$ & Pos & Pos & Neg \\
\hline 15 & AIDP & 37 & 49 & 7 & 88 & 48 & 94 & $\mathrm{NA}$ & $\operatorname{lgG}+/ \lg M+$ & $\mathrm{Neg}$ & $\mathrm{Neg}$ & $\mathrm{Neg}$ \\
\hline
\end{tabular}

confirmed bilateral patchy denervation, predominantly of the upper trunk of the brachial plexus. For 2 patients (patients 7 and 10), analysis of CSF showed high levels of proteins, levels of cells in reference ranges, and glucose level within reference range. HEV PCR of a CSF specimen was not done.

HEV was diagnosed after IgM against HEV was detected in 1 patient (patient 9) and after HEV RNA was detected in the serum of 3 patients (patients 7, 8, 10). Patients 7 and 10 were given ribavirin (for, respectively, 3 weeks and 2 months) at a dose of $800 \mathrm{mg} /$ day. This treatment was well tolerated. They also received intravenous immunoglobulin (IVIg) at a dose of $25 \mathrm{~g} /$ day (patient 7) or $35 \mathrm{~g} /$ day (patient 10) for 5 days. All patients but 1 had persistent weakness at the last follow-up (median 71 weeks [range 16-126 weeks]); none had received a control electromyogram. Assessment of patients through disability scales was not possible because this study was retrospective and involved many centers. Notably, the only asymptomatic patient at follow-up was the patient that received both ribavirin and IVIg.

\section{Meningoradiculitis}

Three patients ( 2 women and 1 man, patients 11-13) had meningoradiculitis. They were, respectively, 74, 54, and 33 years of age. These patients sought treatment for meningitis symptoms (headache, photophobia) and radiculitis with pain and paresthesia restricted to 1 or a few radicular topographies. CSF was clear and showed lymphocytic meningitis with $>90 \%$ lymphocytes, a high level of protein $(0.79-1.37 \mathrm{~g} / \mathrm{L}$, reference range $0.28-0.53 \mathrm{~g} / \mathrm{L})$, and glucose levels within reference ranges. Patient 11 had jaundice. PCR of all serum samples from all patients with meningoradiculitis showed HEV RNA. For 2 patients, PCR of CSF was positive for HEV (patients 11 and 12).
One woman was breast feeding (patient 13); HEV was detected in her serum but not in breast milk. PCR detected $\mathrm{HEV}$ in fecal samples from 2 patients (patients 11 and 13). Patient 11 was treated with IVIg at $0.5 \mathrm{~g} / \mathrm{kg} /$ day for 4 days. No patient was symptomatic at the last follow-up visit. The median time to follow-up was 119 weeks (range 77-161 weeks).

\section{Acute Inflammatory Demyelinating Polyradiculoneuropathy}

Two patients exhibited acute inflammatory demyelinating polyradiculoneuropathy: 1 had GBS, and 1 had MillerFisher syndrome. Patient 14, a 60-year-old woman, was hospitalized for GBS. Initially, she had asthenia and acute low back pain. She had a positive viral load for HEV IgG and IgM. A neurologic examination revealed generalized areflexia and weakness in the lower limbs. GBS was confirmed in nerve-conduction studies. She had no hepatic symptoms. CSF analysis showed a high level of protein (2 $\mathrm{g} / \mathrm{L}$, reference range $0.28-0.53 \mathrm{~g} / \mathrm{L}$ ) and no HEV RNA. She was treated with IVIg for 5 days at a dose of $400 \mathrm{mg} /$ day, and the symptoms partially regressed. By 5 weeks later, weakness of the lower limbs had improved, but she still experienced persistent areflexia.

Patient 15, a 54-year-old man, was hospitalized for weight loss. A neurologic examination revealed quadridistal hypoesthesia with ataxia, areflexia, and diplopia due to paresia of the right VI nerve. CSF protein concentration was elevated $(1.46 \mathrm{~g} / \mathrm{L}$, reference range $0.28-0.53$ $\mathrm{g} / \mathrm{L}$ ), and albumino-cytologic dissociation was found. Nerve-conduction studies confirmed demyelinating neuropathy. These findings were conclusive for Miller-Fisher syndrome. He had no hepatic symptoms. Serum was positive for IgM against HEV. Serum and fecal samples were negative for HEV by PCR. He received IVIg for 5 days at a dosage of $2 \mathrm{~g} / \mathrm{kg}$ and was hospitalized for 1 week. His 
Table 3. Average biological values of the 4 groups of patients with hepatitis E virus-linked neurological disorders*

\begin{tabular}{|c|c|c|c|c|c|c|c|c|}
\hline Disorder & $\begin{array}{l}\text { Age, y } \\
\text { (range) }\end{array}$ & $\begin{array}{l}\text { Sex } \\
\text { ratio }\end{array}$ & AST, IU/L ( \pm SD) & $\mathrm{ALT}, \mathrm{IU} / \mathrm{L}( \pm \mathrm{SD})$ & $\mathrm{PT}, \%( \pm \mathrm{SD})$ & $\begin{array}{c}\text { Bilirubin, } \\
\mu \mathrm{mol} / \mathrm{L}( \pm \mathrm{SD})\end{array}$ & $\begin{array}{c}\text { ALKP, IU/L ( } \pm \\
\text { SD })\end{array}$ & $\begin{array}{c}\text { GGT, IU/L ( } \pm \\
\text { SD) }\end{array}$ \\
\hline $\mathrm{MM}$ & $54(25-77)$ & 1 & $150( \pm 200) \dagger$ & $835( \pm 1,396)$ & $92.8( \pm 7.5)$ & $25.6( \pm 32)$ & $328.5( \pm 198)$ & $166.2( \pm 95) \dagger$ \\
\hline PTS & $55(51-56)$ & 6 & $740.7( \pm 503)$ & $1,401.25( \pm 647)$ & $94.5( \pm 4.9)$ & $22.2( \pm 13)$ & $355( \pm 211)$ & $476.5( \pm 245)$ \\
\hline MR & $54(33-74)$ & 2 & $687.7( \pm 915)$ & $544.67( \pm 288)$ & $91.3( \pm 13.3)$ & $38.9( \pm 54)$ & $358.67( \pm 305)$ & $248.3( \pm 253)$ \\
\hline AIDP & 57 (54-60) & 1 & $75( \pm 54)$ & $216( \pm 236)$ & $97( \pm 4)$ & $20.6( \pm 19)$ & $281( \pm 272)$ & $415( \pm 519)$ \\
\hline
\end{tabular}

neurologic symptoms improved but did not totally disappear until $>13$ weeks of follow-up (persistent ataxia).

\section{Discussion}

This study shows the wide spectrum of neurologic injuries associated with patients with an acute HEV autochthonous infection. Because the study was retrospective, it was not possible to identify the prevalence of HEV infection in patients with neurologic symptoms or the prevalence of neurologic symptoms in patients with HEV infection.

Neurologic symptoms could be divided into 4 entities. Notably, the first dominant finding was mononeuritis multiplex, observed in 6 of the 15 patients, with asymmetric, asynchronous, and painful segmental nerve involvement. This condition was also the main entity in the original report, which also included immunocompromised patients with chronic HEV-3 infection (5). In previous reports in immunocompetent patients, painful peripheral neuropathy has rarely been reported (8). However, mononeuritis multiplex is a common complication in immune and viral diseases. A vasculitis process can be hypothesized, but none of the patients in this study underwent a nerve biopsy. Additional investigations, including anatomopathologic exploration, would be needed to further explore the physiopathologic (antiviral and/or immunosuppressive) pathways.

The next most frequent manifestation was PTS, also called brachial neuritis or neuralgic amyotrophy, which was found in 4 patients. PTS is a rare pathologic condition, defined by sudden, acute, and unbearable pain across the top of the shoulder, followed by severe amyotrophy. As was exhibited by the patients described here, PTS can be unilateral or bilateral but is asymmetric. A recent study reported cases of acute HEV infection in a cohort of 47 patients from Cornwall (UK) and the Netherlands (12); 5 cases $(10.6 \%)$ of acute HEV infection were identified, indicating that HEV may be a major cause of PTS in industrialized countries with a high prevalence of HEV. That study also suggested that HEV-associated brachial neuritis more commonly produces bilateral symptoms and signs than brachial neuritis produced by other causes. In our study, 3 of 4 patients had bilateral symptoms. Three of the 4 patients with PTS had neurologic sequelae at the last follow-up (71 weeks), which suggests that concomitant HEV infection may represent a poor prognostic factor. Van Eijk et al. (12) found that all 5 of their HEV-positive patients exhibited persistent weakness at 6 months.

There is no specific treatment identified for PTS, but it is known to be immune mediated. However, we cannot exclude direct infection of the brachial plexus. Three of the 4 patients in our study had serum samples positive for HEV by PCR, indicating active replication. Two patients were treated with ribavirin as an antiviral therapy. This antiviral therapy is recommended to treat chronic hepatitis E in organ-transplant recipients $(16,17)$. Case reports on the treatment of acute HEV infection in immunocompetent patients have been published, with promising results $(18-21)$. We found that the only patient who had no persisting symptoms at the last follow-up had been treated with a combination of ribavirin and IVIg.

The third neurologic entity we found was meningoradiculitis in 3 patients. HEV was detected in the CSF of 1 case-patient, indicating neurotropism and the direct effect of HEV. This condition is probably the only one in which HEV may be directly responsible for the neurologic manifestations. No neurologic sequelae were seen in this group. A previous study found quasispecies compartmentalization in an immunocompromised patient with neurologic manifestations, and its temporal association suggests that neurologic symptoms could be linked to the emergence of neurotropic variants (22). The factors associated with HEV neurotropism need to be investigated further.

The last entity was acute inflammatory demyelinating polyradiculoneuropathy, which was seen in 2 patients. This condition can be classically triggered by many viruses, including hepatotropic viruses (23). An immune response that cross-reacts with axonemal or Schwann cell antigens is elicited and results in damage to the peripheral nerves. Both patients had persisting neurologic symptoms, commonly seen in this disease (11). Although several studies have demonstrated that HEV infection can induce GBS, this condition was found in only 2 of our patients. In a cohort of GBS case-patients from Bangladesh, seroprevalence of IgM against HEV was $11 \%$, compared with $2 \%$ in a control group of patients with other 
neurologic disease (7). The frequency of HEV infection was recently determined in a cohort of 201 patients with GBS in the Netherlands and was found to have occurred in $5 \%(11)$.

The number of patients in this study is too small to draw definitive conclusions on the sex ratio for these conditions, but the ratio was highest in the PTS group. We also found that neurologic disorders occurred only in those with a HEV $3 \mathrm{f}$ genotype, although this is the most common genotype in France (24), so other HEV subtypes and genotypes may induce neurologic symptoms (5). Moreover, because only patients with elevated liver enzyme levels were included, neurologic complications were probably underestimated in this study, in particular, for GBS and PTS, for which conditions the neurologic symptoms are often delayed after the initial event is triggered.

Patients with PTS had significantly higher values in liver enzyme tests (aspartate aminotransferase, g-glutamyl transpeptidase) than patients with mononeuritis multiplex. We have no definitive explanation, but this finding could be due to the earlier appearance of PTS symptoms during the course of HEV infection.

Three patients were treated with ribavirin with the aim of shortening the disease's duration: the 2 PTS patients and 1 patient with mononeuritis multiplex. One needed blood transfusions and erythropoietin. Whether ribavirin shortened the evolution of neurologic symptoms, particularly for patients with PTS, needs to be studied further.

One limitation of our study is the retrospective sampling by emailing through the French Liver Association. Although this method provides the advantage of reaching most practitioners who diagnose HEV infection throughout France, it may have induced an ascertainment bias, that is, the true frequency of the neurologic symptoms during HEV infection is difficult to assess. In addition, patients with neurologic symptoms who were not referred to a hepatologist obviously were not accounted for.

In summary, HEV-3 infection can induce a wide range of neurologic symptoms, including mononeuritis multiplex, PTS, meningoradiculitis, and inflammatory demyelinating polyradiculoneuropathy. Sequelae were seen with mononeuropathy multiplex, PTS, and inflammatory demyelinating polyradiculoneuropathy. Only 2 patients had overt hepatitis with jaundice. Therefore, we recommend screening patients with elevated liver enzyme levels and neurologic symptoms for HEV infection, regardless of other symptoms. Treatment with ribavirin needs to be assessed further.

Dr. Blasco-Perrin was an intern from 2010 to 2015 at the Toulouse University hospital in the gastrointestinal and hepatology units. She will be a fellow in the hepatology unit, Purpan Hospital, CHU Toulouse, France, in 2016. . Her research interests focus on viral hepatitis, in particular, hepatitis E.

\section{References}

1. Kamar N, Bendall R, Legrand-Abravanel F, Xia NS, Ijaz S, Izopet J, et al. Hepatitis E. Lancet. 2012;379:2477-88. http://dx.doi.org/10.1016/S0140-6736(11)61849-7

2. Péron JM, Bureau C, Poirson H, Mansuy JM, Alric L, Selves J, et al. Fulminant liver failure from acute autochthonous hepatitis $\mathrm{E}$ in France: description of seven patients with acute hepatitis $\mathrm{E}$ and encephalopathy. J Viral Hepat. 2007;14:298-303. http://dx.doi.org/10.1111/j.1365-2893.2007.00858.x

3. Kamar N, Selves J, Mansuy JM, Ouezzani L, Peron JM, Guitard J, et al. Hepatitis E virus and chronic hepatitis in organ-transplant recipients. N Engl J Med. 2008;358:811-7. http://dx.doi.org/ 10.1056/NEJMoa0706992

4. Tavitian S, Peron JM, Huynh A, Mansuy JM, Ysebaert L, Huguet F, et al. Hepatitis E virus excretion can be prolonged in patients with hematological malignancies. J Clin Virol. 2010;49:141-4. http://dx.doi.org/10.1016/j.jcv.2010.06.016

5. Kamar N, Bendall RP, Peron JM, Cintas P, Prudhomme L, Mansuy JM, et al. Hepatitis E virus and neurologic disorders. Emerg Infect Dis. 2011;17:173-9. http://dx.doi.org/10.3201/ eid1702.100856

6. Cheung MC, Maguire J, Carey I, Wendon J, Agarwal K. Review of the neurological manifestations of hepatitis E infection. Ann Hepatol. 2012;11:618-22.

7. GeurtsvanKessel CH, Islam Z, Mohammad QD, Jacobs BC, Endtz HP, Osterhaus AD. Hepatitis E and Guillain-Barré syndrome. Clin Infect Dis. 2013;57:1369-70. http://dx.doi.org/10.1093/ cid/cit512

8. Woolson KL, Forbes A, Vine L, Beynon L, McElhinney L, Panayi V, et al. Extra-hepatic manifestations of autochthonous hepatitis E infection. Aliment Pharmacol Ther. 2014;40:1282-91. http://dx.doi.org/10.1111/apt.12986

9. Del Bello A, Arne-Bes MC, Lavayssiere L, Kamar N. Hepatitis E virus-induced severe myositis. J Hepatol. 2012;57:1152-3. http://dx.doi.org/10.1016/j.jhep.2012.05.010

10. Deroux A, Brion JP, Hyerle L, Belbezier A, Vaillant M, Mosnier E, et al. Association between hepatitis $\mathrm{E}$ and neurological disorders: two case studies and literature review. J Clin Virol. 2014;60:60-2.

11. Van den Berg B, van der Eijk AA, Pas SD, Hunter JG, Madden RG, Tio-Gillen AP, et al. Guillain-Barré syndrome associated with preceding hepatitis E virus infection. Neurology. 2014; 82:491-7.

12. Van Eijk JJ, Madden RG, van der Eijk AA, Hunter JG, Reimerink JH, Bendall RP, et al. Neuralgic amyotrophy and hepatitis E virus infection. Neurology. 2014;82:498-503.

13. Abravanel F, Chapuy-Regaud S, Lhomme S, Miedouge M, Peron JM, Alric L, et al. Performance of anti-HEV assays for diagnosing acute hepatitis E in immunocompromised patients. J Clin Virol. 2013;58:624-8. http://dx.doi.org/10.1016/j.jcv.2013.10.003

14. Despierres LA, Kaphan E, Attarian S, Cohen-Bacrie S, Pelletier J, Pouget J, et al. Neurologic disorders and hepatitis E, France, 2010. Emerg Infect Dis. 2011;17:1510-2.

15. Legrand-Abravanel F, Mansuy JM, Dubois M, Kamar N, Peron JM, Rostaing L, et al. Hepatitis E virus genotype 3 diversity, France. Emerg Infect Dis. 2009;15:110-4. http://dx.doi.org/10.3201/ eid1501.080296

16. Mallet V, Nicand E, Sultanik P, Chakvetadze C, Tesse S, Thervet E, et al. Brief communication: case reports of ribavirin treatment for chronic hepatitis E. Ann Intern Med. 2010;153:85-9. http://dx.doi.org/10.7326/0003-4819-153-2-201007200-00257

17. Kamar N, Rostaing L, Abravanel F, Garrouste C, Lhomme S, Esposito L, et al. Ribavirin therapy inhibits viral replication on patients with chronic hepatitis e virus infection. Gastroenterology. 2010;139:1612-8. http://dx.doi.org/10.1053/j.gastro.2010.08.002

18. Péron JM, Dalton H, Izopet J, Kamar N. Acute autochthonous hepatitis $\mathrm{E}$ in western patients with underlying chronic liver 
disease: a role for ribavirin? J Hepatol. 2011;54:1323-4; author reply 4-5. http://dx.doi.org/10.1016/j.jhep.2011.01.009

19. Pischke S, Hardtke S, Bode U, Birkner S, Chatzikyrkou C, Kauffmann W, et al. Ribavirin treatment of acute and chronic hepatitis E: a single-centre experience. Liver Int. 2013; 33:722-6. DOI:10.1111/liv.12114

20. Goyal R, Kumar A, Panda SK, Paul SB, Acharya SK.

Ribavirin therapy for hepatitis E virus-induced acute on chronic liver failure: a preliminary report. Antivir Ther. 2012;17:1091-6. http://dx.doi.org/10.3851/IMP2317

21. Gerolami R, Borentain P, Raissouni F, Motte A, Solas C, Colson P. Treatment of severe acute hepatitis E by ribavirin. J Clin Virol. 2011;52:60-2. http://dx.doi.org/10.1016/j.jcv.2011.06.004

22. Kamar N, Izopet J, Cintas P, Garrouste C, Uro-Coste E, Cointault $\mathrm{O}$, et al. Hepatitis E virus-induced neurological symptoms in a kidney-transplant patient with chronic hepatitis. Am J Transplant. 2010;10:1321-4. http://dx.doi.org/10.1111/ j.1600-6143.2010.03068.x

23. Hughes RACH, Cornblath DR. Guillain-Barré syndrome. Lancet. 2005;366:1653-66. http://dx.doi.org/10.1016/ S0140-6736(05)67665-9

24. Mansuy JM, Abravanel F, Miedouge M, Mengelle C, Merviel C, Dubois M, et al. Acute hepatitis E in south-west France over a 5-year period. J Clin Virol. 2009;44:74-7. http://dx.doi.org/ 10.1016/j.jcv.2008.09.010

Address for correspondence: J.-M. Peron, CHU Toulouse, PurpanService Hépato Gastro Entérologie, Place du Dr Baylac, Pavillon Dieulafoy, Toulouse 31039, France; email: peron.jm@chu-toulouse.fr

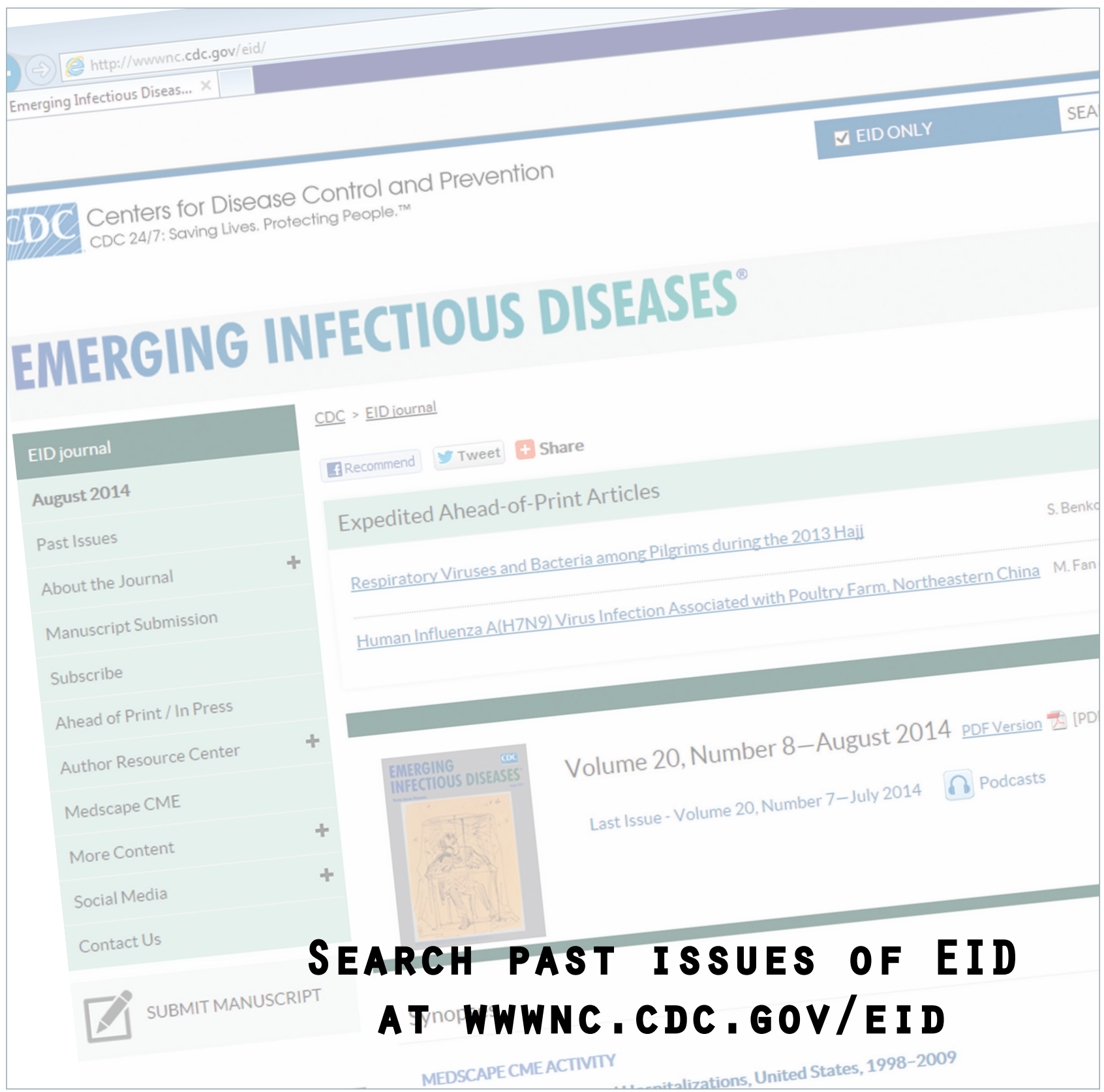

